\title{
MAJOR ATHLETIC COMPETITION PERFORMANCE AND REALIZATION IN THE DISCIPLINE 110 M HURDLES (MEN)
}

\author{
G. Gutev* \\ Department “Track \& Field”, National Sports Academy "Vassil Levski”, Sofia, Bulgaria
}

\begin{abstract}
The main aim of the research is to examine performance and realization of elite $110 \mathrm{~m}$ hurdles during major athletics competitions (World Athletics Championships-WAC). We analyze the performance of finalists in major competitions in details (including results during preliminary stages) and perform specific statistical analysis. Based on study results we presented effective structural pattern for competing for WAC in the $110 \mathrm{~m}$ hurdles discipline. Finalists' results from heats and semi-finals have certain similarities. Athletes compete in preliminary stages just to proceed to the next stage. The finals give the opportunity for both maximum sports performance and ranking. Based on their performance and sport realization in major events we can define 3 types of athlete: medal winners, hurdlers finished in 4th place, athletes with a ranking between 5th and 8th place. We can mark as a separate tendency that hurdlers from the second and third groups often reach 100\% of their performance abilities (register PB result for the corresponding year) in the semi-finals only to qualify for the final.
\end{abstract}

Key words: sport realization, men, $110 \mathrm{~m}$ hurdles, world championships

\section{INTRODUCTION}

Professional sport in modern times is characterized with changes in almost all aspects: political, economic and social. They have direct influence on sport in general. Due to these changes we find different concepts regarding strategy of training and competing in major events. (5)

Athletics is an inseparable part of sport. Major athletic competitions are organized regularly on determined periods on geographical principal. The most entitled tournaments in athletics globally are the Olympic games (OG) and Worlds Athletics Championships (WAC) on international level and European Athletics Championships (EAC) on European continent level (9). The first and the last competitions (OG and EAU) are two of the oldest sport events in athletics history. We find many changes during their history which have influence on discipline development, competition rules and results.

Correspondence to: Prof. Veneta

Gaydardzhieva, PhD, Faculty of Economics,

Trakia University, Stara Zagora, Bulgaria, Phone:

+359 42699 424, E-mail: veng.sz@abv.bg
On the other hand, WAC is relatively new tournament, founded in 1983. From its start as a major competition to nowadays there are in total 17 championships organized in different continents and countries. (10)

Sport realization of elite athletes in major competitions is always a live question due to the constant development of the sport. Also, the best examples from which we can take example are the athletes with the best results respectively the finalists in the WAC. $(1,6,7)$ Part of the athletics family is the discipline 110 $\mathrm{m}$ hurdles (men). Hurdling is sprint racing with 10 obstacles (hurdles). Hurdles are the main difference between flat sprinting and hurdle running, as athletes use hurdle stride to run over the obstacles. Although we find the same main phases as sprint running acceleration, maximal velocity and deceleration - they must be applied to the unique rhythm changes. For elite performance athletes must adjust their mechanics to create the needed stride patter to clear the hurdles in the most effective way. $(1,4,8)$ 
THE MAIN OBJECTIVE OF THE STUDY

The main purpose of the following study is to reveal detailed information regarding competition performance and realization in major international competitions. This will give us an impartial assessment of athlete's best performance abilities and the way they perform and utilize their potential during major championships.

Based on the theory, that WAC is a relatively new tournament and sport realizations are not influenced by changes in different sport aspects we assume, that athletes are supposed to present their best sport potential during the different stages of the competition. Tendencies and conclusion based on WAC should be with high validity and informativity for the near future. This gives us firm ground to analyze and compare sport realization in different championships for a period of time.

\section{MATERIALS AND METHODS}

The aim of our study is to reveal sport performance and realization of contemporary elite athletes in $110 \mathrm{~m}$ hurdle discipline. Knowing performance patterns of elite athletes from major competition will contribute in training and competition modeling and will help performance optimization.

For the purpose of the study we managed the following research tasks:

- Analysis of World Athletics (WA) discipline groups and the internationals structure of competitions governed by WA (former IAAF) from its foundation in 1983.

- Analysis of World Athletics Championships competition structure evolution and qualification rules in the discipline $110 \mathrm{~m}$ hurdles (men).

- Analysis on finalist's performance in all stages in of the event.
GUTEV G.

- Revealing athletes with the biggest contribution in analyzed championship.

Respondents are all hurdlers, finalists at WAC - they present the elite of the discipline in the studied period. We examine their sport performance and realization via sport results (measured in seconds) in the most important international competition for the non-Olympic years.

For this purpose, we analyze WAC finalists' results in $110 \mathrm{~m}$ hurdles: from all stages of the competition and their personal best result (PB) for the championship corresponding year.

Research data was processed with the following statistical methods: descriptive statistics, frequency analysis, Student's T-test for paired samples and correlation analysis. All methods were used on SPSS 22.0 software. (3)

\section{RESULTS AND DISCUSSION}

On a structural level, the hurdle events are an inevitable part of each World Athletics Championship from the tournament foundation in 1983. Figure 1 presents the groups of disciplines presented in the WC competition program (note that the group disciplines marked in grey have their own world championship organized by World Athletics). WAC organization periods and data regarding the structure of all 17 championships are presented in table 1. From its foundation, it was organized in a period of 4 years (similar to OG) until 1991 (the 3rd WAC). After that, probably due to the tendency in the sport for commercialization athletics governing body IAAF (now WA), took a decision to organize the planetary athletics championships in a period of 2 years, which in our opinion has a positive effect on athletics development worldwide.

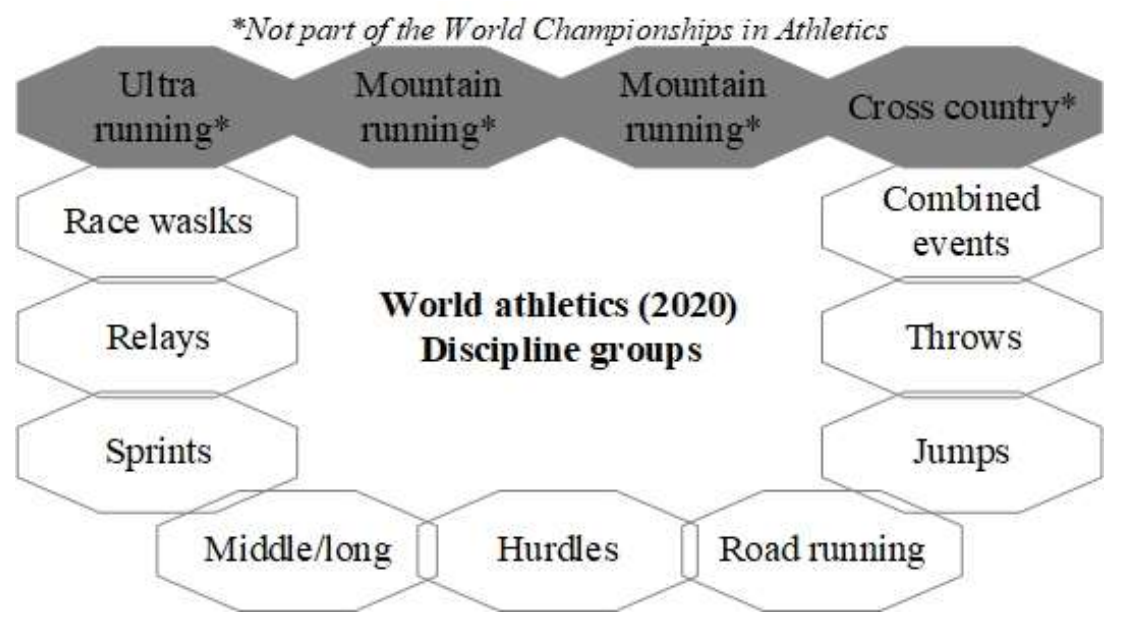

Figure 1. Structure of World Athletics discipline groups (2020). 
Table 1 presents championship competition structure in $110 \mathrm{~m}$ hurdles (men). It reveals detailed information regarding the number of heats, quarter-finals (period 1995-1999), semi-
GUTEV G.

finals and final. It also gives us data about the number of participating athletes and the structure of the different championships.

Table 1. World Championships organization periods and competition structure in the discipline 110 $m$ hurdles.

\begin{tabular}{|c|c|c|c|c|c|c|}
\hline \multirow{2}{*}{ No } & \multirow{2}{*}{ year } & \multirow{2}{*}{$\begin{array}{c}\text { championship } \\
\text { duration } \\
\text { (years) }\end{array}$} & \multicolumn{4}{|c|}{$\begin{array}{c}\text { championship structure (№ of } \\
\text { heats) }\end{array}$} \\
\cline { 5 - 8 } & & & heats & $\begin{array}{c}\text { quarter- } \\
\text { final }\end{array}$ & $\begin{array}{c}\text { semi- } \\
\text { final }\end{array}$ & final \\
\hline 1st & 1983 & & 4 & & 2 & 1 \\
\hline 2nd & 1987 & 4 & 5 & & 2 & 1 \\
\hline 3rd & 1991 & 4 & 5 & & 2 & 1 \\
\hline 4th & 1993 & 2 & 6 & & 3 & 1 \\
\hline 5th & 1995 & 2 & 6 & 4 & 2 & 1 \\
\hline 6th & 1997 & 2 & 6 & 4 & 2 & 1 \\
\hline 7th & 1999 & 2 & 6 & 4 & 2 & 1 \\
\hline 8th & 2001 & 2 & 6 & & 3 & 1 \\
\hline 9th & 2003 & 2 & 5 & & 3 & 1 \\
\hline 10th & 2005 & 2 & 6 & & 3 & 1 \\
\hline 11th & 2007 & 2 & 5 & & 3 & 1 \\
\hline 12th & 2009 & 2 & 6 & & 3 & 1 \\
\hline 13th & 2011 & 2 & 4 & & 2 & 1 \\
\hline 14th & 2013 & 2 & 4 & & 2 & 1 \\
\hline 15th & 2015 & 2 & 5 & & 3 & 1 \\
\hline 16th & 2017 & 2 & 5 & & 3 & 1 \\
\hline 17th & 2019 & 2 & 5 & & 3 & 1 \\
\hline
\end{tabular}

Details concerning qualification rules in WAC are presented on Table 2. During the first three WAC, qualification for the next competition round was made based on the best results of the athletes. This approach requires maximal sport realization from each athlete from the start of the tournament and presumes a drop in the sports results at the end of the competition (finals). We can note that this way results from the finals are influenced negatively.

The qualification pattern evaluated in the next championships was based on the regulations: athletes finishing in the first places of heats or semi-finals are receiving direct qualification for the next round (marked with Q). A chance for qualification to the next competition round is also given to athletes with the so called "fastest loosing times" - marked with q.

From 2001 to the last WAC in 2019 we find similar qualification rules and competition structure. In our opinion it is the most efficient way of conducting a competition with similar to the $110 \mathrm{~m}$ hurdle running characteristics. This gives us basis for analysis and compare of sport realization in single competition of hurdlers with high sport qualification for this time period.

Based on Table 1 and Figure 2 we can note out that the chosen structural pattern for conducting WAC in the $110 \mathrm{~m}$ hurdles disciplines is as follows: heats, semi-final and final hierarchical levels. Based on the period that it was applied (a period of 18 years) we assume that it is the most efficient and athlete's friendly way of competing in the discipline and revealing their best performance. The number of heats may differ and is connected with the number of athletesparticipants in the discipline. We present Table 3 in order to widen our analysis regarding the performance of the finalists in $110 \mathrm{~m}$ hurdles discipline during preliminary parts of the tournament - heats and semi-finals (for the period 2001 Edmontn-2019 Doha or 8th-17th WC). We selected this period of 18 years due to the following facts: first it is 
closest to our time and second the competition structure is similar so analysis will be objective. Detailed review of the statistical indexes range $(\mathrm{R})$ and standard deviation $(\mathrm{S})$ gives us the ground to summarize that results of finalists from heats and semi-finals are relatively similar (heats $\mathrm{R} \approx 0,14-0,46$ and $\mathrm{S} \approx 0,08-0,17$; semi-finals $\mathrm{R} \approx 0,16-0,45$ and
GUTEV G.

$\mathrm{S} \approx 0,05-0,14)$. The main difference is minor improvement in sport performance (result), but only to the level which will give athletes promotion to the next stage of competition. On the other hand, finals of major championships are field of expression of two things - winning and achieving major sport result.

Table 2. Competition qualification rules.

\begin{tabular}{|c|c|c|c|c|c|}
\hline \multirow{2}{*}{ № } & \multirow{2}{*}{ year } & \multicolumn{4}{|c|}{ part of the competition } \\
\hline & & heats & quarter-final & semi-final & Final \\
\hline 1st & 1983 & 16 best results & & 8 best results & \\
\hline 2nd & 1987 & 16 best results & & 8 best results & \\
\hline 3rd & 1991 & best 3 in each heat $Q$ & & best 4 in each semi-final Q & \\
\hline 4th & 1993 & $\begin{array}{c}\text { best } 3 \text { in each heat } Q+6 \\
\text { fastest times } q\end{array}$ & & $\begin{array}{c}\text { best } 2 \text { in each semi-final } Q+ \\
2 \text { fastest times q }\end{array}$ & \\
\hline 5 th & 1995 & $\begin{array}{c}\text { best } 3 \text { in each heat } Q+8 \\
\text { fastest times } \mathrm{q}\end{array}$ & $\begin{array}{c}\text { best } 4 \text { in each quarter-final Q } \\
+4 \text { fastest times } \mathrm{q}\end{array}$ & best 4 in each semi-final $Q$ & \\
\hline 6th & 1997 & $\begin{array}{l}\text { best } 5 \text { in each heat } Q+2 \\
\text { fastest times } \mathrm{q}\end{array}$ & $\begin{array}{c}\text { best } 3 \text { in each quarter-final Q } \\
+4 \text { fastest times } \mathrm{q}\end{array}$ & best 4 in each semi-final $Q$ & \\
\hline 7th & 1999 & $\begin{array}{l}\text { best } 4 \text { in each heat } Q+8 \\
\text { fastest times } \mathrm{q}\end{array}$ & best 4 in each quarter-final $Q$ & best 4 in each semi-final $Q$ & \\
\hline 8th & 2001 & $\begin{array}{l}\text { best } 3 \text { in each heat } Q+6 \\
\text { fastest times } \mathrm{q}\end{array}$ & & $\begin{array}{c}\text { best } 2 \text { in each semi-final } Q+ \\
2 \text { fastest times q }\end{array}$ & \\
\hline 9th & 2003 & $\begin{array}{c}\text { best } 3 \text { in each heat } Q+9 \\
\text { fastest times } \mathrm{q}\end{array}$ & & $\begin{array}{c}\text { best } 2 \text { in each semi-final } Q+ \\
2 \text { fastest times q }\end{array}$ & $\frac{\tilde{d}}{0}$ \\
\hline 10th & 2005 & $\begin{array}{c}\text { best } 3 \text { in each heat } Q+6 \\
\text { fastest times } \mathrm{q}\end{array}$ & & $\begin{array}{c}\text { best } 3 \text { in each semi-final } Q+ \\
2 \text { fastest times q }\end{array}$ & $\begin{array}{l}\text { 齐 } \\
\infty\end{array}$ \\
\hline 11th & 2007 & $\begin{array}{l}\text { best } 3 \text { in each heat } Q+6 \\
\text { fastest times } \mathrm{q}\end{array}$ & & $\begin{array}{c}\text { best } 2 \text { in each semi-final } Q+ \\
2 \text { fastest times q }\end{array}$ & \\
\hline 12th & 2009 & $\begin{array}{l}\text { best } 3 \text { in each heat } Q+6 \\
\text { fastest times } \mathrm{q}\end{array}$ & & $\begin{array}{c}\text { best } 2 \text { in each semi-final } Q+ \\
2 \text { fastest times q }\end{array}$ & \\
\hline 13th & 2011 & $\begin{array}{l}\text { best } 3 \text { in each heat } Q+4 \\
\text { fastest times } \mathrm{q}\end{array}$ & & $\begin{array}{c}\text { best } 3 \text { in each semi-final } Q+ \\
2 \text { fastest times q }\end{array}$ & \\
\hline 14th & 2013 & $\begin{array}{l}\text { best } 3 \text { in each heat } Q+4 \\
\text { fastest times } q\end{array}$ & & $\begin{array}{c}\text { best } 3 \text { in each semi-final } Q+ \\
2 \text { fastest times q }\end{array}$ & \\
\hline 15th & 2015 & $\begin{array}{l}\text { best } 4 \text { in each heat } Q+4 \\
\text { fastest times q }\end{array}$ & & $\begin{array}{c}\text { best } 2 \text { in each semi-final Q + } \\
2 \text { fastest times q }\end{array}$ & \\
\hline 16th & 2017 & $\begin{array}{l}\text { best } 4 \text { in each heat } Q+4 \\
\text { fastest times } q\end{array}$ & & $\begin{array}{c}\text { best } 2 \text { in each semi-final } Q+ \\
2 \text { fastest times q }\end{array}$ & \\
\hline 17th & 2019 & $\begin{array}{l}\text { best } 4 \text { in each heat } Q+4 \\
\text { fastest times q }\end{array}$ & & $\begin{array}{c}\text { best } 2 \text { in each semi-final } Q+ \\
2 \text { fastest times q }\end{array}$ & \\
\hline
\end{tabular}

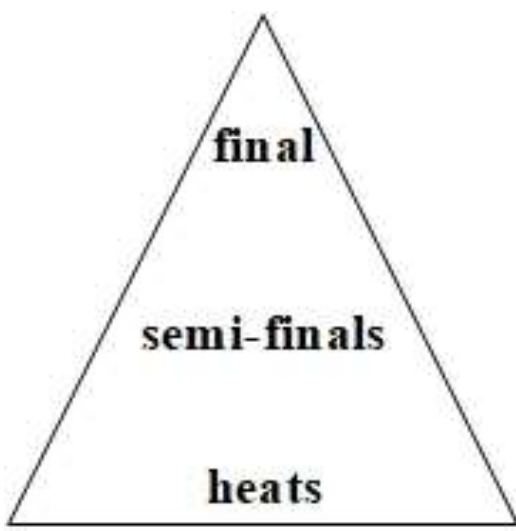

Figure 2. WC 110 m hurdles competition hierarchical structure. 
GUTEV G.

Table 3. Descriptive statistics of WC finalists results during the three parts of the tournaments.

\begin{tabular}{|c|c|c|c|c|c|c|c|c|c|c|c|c|c|c|c|}
\hline \multirow{2}{*}{ WC } & \multicolumn{9}{|c|}{ final } & \multicolumn{1}{|c|}{ semi-finals } & \multicolumn{5}{c|}{ heats } \\
\cline { 2 - 17 } & mean & min. & max. & R & S & mean & min. & max. & R & S & mean & min. & max. & R & S \\
\hline 8th & 13,41 & 13,04 & 13,84 & 0,80 & 0,30 & 13,34 & 13,19 & 13,43 & 0,24 & 0,08 & 13,45 & 13,21 & 13,63 & 0,42 & 0,17 \\
\hline 9th & 13,36 & 13,12 & 13,57 & 0,45 & 0,18 & 13,43 & 13,19 & 13,55 & 0,36 & 0,13 & 13,48 & 13,42 & 13,56 & 0,14 & 0,05 \\
\hline 10th & 13,25 & 13,07 & 13,48 & 0,41 & 0,19 & 13,35 & 13,23 & 13,43 & 0,20 & 0,08 & 13,88 & 13,73 & 13,96 & 0,23 & 0,08 \\
\hline 11th & 13,16 & 12,95 & 13,39 & 0,44 & 0,16 & 13,26 & 13,19 & 13,35 & 0,16 & 0,06 & 13,38 & 13,22 & 13,53 & 0,31 & 0,10 \\
\hline 12th & 13,32 & 13,14 & 13,57 & 0,43 & 0,18 & 13,32 & 13,18 & 13,43 & 0,25 & 0,09 & 13,52 & 13,35 & 13,62 & 0,27 & 0,08 \\
\hline 13th & 13,44 & 13,16 & 13,67 & 0,51 & 0,21 & 13,37 & 13,11 & 13,56 & 0,45 & 0,14 & 13,32 & 13,19 & 13,52 & 0,33 & 0,11 \\
\hline 14th & 13,27 & 13,00 & 13,51 & 0,51 & 0,16 & 13,30 & 13,17 & 13,44 & 0,27 & 0,10 & 13,29 & 13,05 & 13,51 & 0,46 & 0,14 \\
\hline 15th & 13,16 & 12,98 & 13,34 & 0,36 & 0,13 & 13,15 & 13,08 & 13,25 & 0,17 & 0,05 & 13,32 & 13,15 & 13,43 & 0,28 & 0,09 \\
\hline 16th & 13,27 & 13,04 & 13,37 & 0,33 & 0,12 & 13,22 & 13,10 & 13,27 & 0,17 & 0,06 & 13,34 & 13,16 & 13,47 & 0,31 & 0,10 \\
\hline 17th & 13,40 & 13,10 & 13,87 & 0,77 & 0,29 & 13,22 & 13,10 & 13,36 & 0,26 & 0,09 & 13,35 & 13,15 & 13,51 & 0,36 & 0,13 \\
\hline
\end{tabular}

Table 3 summarizes information regarding finalist's performance in different stages of WAC. On the other hand, Table 4 reveals descriptive statistics of sport realization based on hurdlers standing in the finals in relative value (percent - \%) of their personal best result for the WAC year.

Table 4. Descriptive analysis of championship sport realization based on personal best result for the corresponding competition year (period 2001-2019) in percentage (\%).

\begin{tabular}{|c|c|c|c|c|}
\hline & & final \% & semi-final \% & series \% \\
\hline mean & \multirow{5}{*}{$\frac{\tilde{E}}{\frac{\tilde{E}}{2}}$} & $99,50 \%$ & $98,58 \%$ & $97,30 \%$ \\
\hline$S$ & & $0,50 \%$ & $0,81 \%$ & $1,71 \%$ \\
\hline $\min$ & & $98,86 \%$ & $97,15 \%$ & $93,58 \%$ \\
\hline $\max$ & & $100,00 \%$ & $99,70 \%$ & $99,62 \%$ \\
\hline $\mathbf{R}$ & & $1,14 \%$ & $2,54 \%$ & $6,04 \%$ \\
\hline mean & \multirow{5}{*}{ 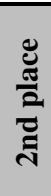 } & $99,54 \%$ & $98,58 \%$ & $97,30 \%$ \\
\hline$S$ & & $0,62 \%$ & $0,75 \%$ & $1,71 \%$ \\
\hline $\min$ & & $97,97 \%$ & $97,24 \%$ & $93,58 \%$ \\
\hline $\max$ & & $100,00 \%$ & $99,54 \%$ & $99,62 \%$ \\
\hline $\mathbf{R}$ & & $2,03 \%$ & $2,30 \%$ & $6,04 \%$ \\
\hline mean & \multirow{5}{*}{$\frac{\stackrel{U}{0}}{2}$} & $99,48 \%$ & $98,99 \%$ & $97,91 \%$ \\
\hline$S$ & & $0,52 \%$ & $0,75 \%$ & $1,87 \%$ \\
\hline $\min$ & & $98,36 \%$ & $97,85 \%$ & $93,32 \%$ \\
\hline $\max$ & & $100,00 \%$ & $100,00 \%$ & $100,00 \%$ \\
\hline $\mathbf{R}$ & & $1,64 \%$ & $2,15 \%$ & $6,68 \%$ \\
\hline mean & \multirow{5}{*}{$\frac{\text { : }}{\frac{\pi}{2}}$} & $98,80 \%$ & $98,50 \%$ & $97,51 \%$ \\
\hline$S$ & & $1,10 \%$ & $1,11 \%$ & $1,72 \%$ \\
\hline $\min$ & & $96,28 \%$ & $96,57 \%$ & $93,19 \%$ \\
\hline $\max$ & & $100,00 \%$ & $99,77 \%$ & $99,24 \%$ \\
\hline $\mathbf{R}$ & & $3,72 \%$ & $3,21 \%$ & $6,04 \%$ \\
\hline
\end{tabular}

Based on research data (Table 4) we can define three groups of finalists based on their performance compared to personal best results for the season:

- The first group includes medal winners (from 1 st to 3rd place). They manage to reveal average between $99,48 \%$ and $99,54 \%$ of their personal abilities for the season in major event in the final run where result matters most. Standard deviation is below $0,62 \%$ and range $2,03 \%$ or less. Also, we find certain tendency in effort performance distribution between heats-semi-final: $\approx 97 \%-98 \%-99 \%$ or more.

\begin{tabular}{|c|c|c|c|c|}
\hline & final $\%$ & semi-final \% & series \% & \\
\hline \multirow{5}{*}{ 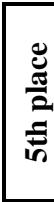 } & $98,99 \%$ & $99,20 \%$ & $98,31 \%$ & mean \\
\hline & $1,21 \%$ & $0,66 \%$ & $1,57 \%$ & $S$ \\
\hline & $95,98 \%$ & $97,82 \%$ & $94,35 \%$ & $\min$ \\
\hline & $100,00 \%$ & $100,00 \%$ & $99,78 \%$ & $\max$ \\
\hline & $4,02 \%$ & $2,18 \%$ & $5,43 \%$ & $\mathbf{R}$ \\
\hline \multirow{5}{*}{ 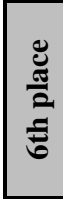 } & $98,83 \%$ & $98,54 \%$ & $98,11 \%$ & mean \\
\hline & $0,71 \%$ & $2,07 \%$ & $1,37 \%$ & $S$ \\
\hline & $97,80 \%$ & $93,14 \%$ & $95,11 \%$ & $\min$ \\
\hline & $100,00 \%$ & $100,00 \%$ & $99,63 \%$ & $\max$ \\
\hline & $2,20 \%$ & $6,86 \%$ & $4,52 \%$ & $\mathbf{R}$ \\
\hline \multirow{5}{*}{ 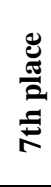 } & $98,04 \%$ & $99,11 \%$ & $98,30 \%$ & mean \\
\hline & $1,24 \%$ & $0,80 \%$ & $1,55 \%$ & $S$ \\
\hline & $96,08 \%$ & $97,60 \%$ & $94,96 \%$ & $\min$ \\
\hline & $100,00 \%$ & $100,00 \%$ & $99,55 \%$ & $\max$ \\
\hline & $3,92 \%$ & $2,40 \%$ & $4,59 \%$ & $\mathbf{R}$ \\
\hline \multirow{5}{*}{ 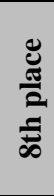 } & $97,91 \%$ & $99,33 \%$ & $98,46 \%$ & mean \\
\hline & $1,42 \%$ & $0,97 \%$ & $1,17 \%$ & $S$ \\
\hline & $95,81 \%$ & $96,98 \%$ & $95,56 \%$ & $\min$ \\
\hline & $99,25 \%$ & $100,00 \%$ & $99,40 \%$ & $\max$ \\
\hline & $3,44 \%$ & $3,02 \%$ & $3,84 \%$ & $\mathbf{R}$ \\
\hline
\end{tabular}

This gives us the ground to state that these hurlers manage to perform the best way they can in major competitions.

- The second group consists of hurdlers qualified on 4th place who are very close to medal table performance pattern but could not manage to reveal their best at the final - final average result is below $99 \%$ of their PB for the year. Heats and semi-final patterns are similar to the first group. Even $100 \%$ of their moment abilities (PB for the year) are not enough for better ranking. 
- The last group from finalists consists of hurdlers with ranking between 5th and 8th place. They must perform average $98 \%$ of their PB for the year just to pass through series (for comparison: $97 \%$ for medalists) and reach average results $99 \%$ (of PB result for the year) to get to finals. This inefficient sport performance distribution lead to underperformance in the final where they
GUTEV G.

reach on average $98 \%$ of $\mathrm{PB}$ results for the year. Standard deviation (S) for results in the final are similar $(\mathrm{S} \approx 0,71-1,42 \%)$.

As a separate tendency we can mark that hurdlers from second and third groups often reach $100 \%$ of their performance abilities (register PB result) in the semi-finals just to qualify for the final.

Table 5. Students' T-test for paired samples.

\begin{tabular}{|c|c|c|c|c|c|c|c|c|c|c|}
\hline \multirow{2}{*}{ index } & \multirow[b]{2}{*}{$\mathbf{n}$} & \multicolumn{2}{|c|}{ case 1} & \multicolumn{2}{|c|}{ case 2} & \multicolumn{3}{|c|}{ Paired differences } & \multicolumn{2}{|c|}{ Statistical significance } \\
\hline & & $\bar{X}_{1}$ & $\mathbf{S}_{1}$ & $\bar{X}_{2}$ & $\mathbf{S}_{2}$ & d & $\mathrm{d} \%$ & Cohen's d & $\mathbf{t}$ & Sig. (2-tailed) \\
\hline \multirow{10}{*}{ ष्छ } & \multirow{10}{*}{ 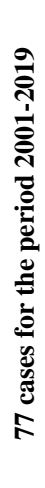 } & \multicolumn{2}{|c|}{ heats } & \multicolumn{2}{|c|}{ semi-final } & & & & & \\
\hline & & 13,44 & 0,20 & 13,29 & 0,11 & 0,15 & 1,1 & 0,81 & 7,09 & 0,00 \\
\hline & & \multicolumn{2}{|c|}{ semi-final } & \multicolumn{2}{|c|}{ final } & & & & & \\
\hline & & 13,29 & 0,11 & 13,30 & 0,21 & $-0,01$ & $-0,1$ & $-0,05$ & $-0,46$ & 0,65 \\
\hline & & \multicolumn{2}{|c|}{ heats } & \multicolumn{2}{|c|}{ final } & & & & & \\
\hline & & 13,44 & 0,20 & 13,30 & 0,21 & 0,14 & 1,0 & 0,51 & 4,45 & 0,00 \\
\hline & & \multicolumn{2}{|c|}{ final } & \multicolumn{2}{|c|}{$\begin{array}{c}\text { PB for year } \\
\text { of WC }\end{array}$} & & & & & \\
\hline & & 13,30 & 0,21 & 13,15 & 0,14 & 0,15 & 1,09 & 0,98 & 8,62 & 0,00 \\
\hline & & \multicolumn{2}{|c|}{$\begin{array}{l}\text { PB for year } \\
\text { of WAC }\end{array}$} & \multicolumn{2}{|c|}{ heats } & & & & & \\
\hline & & 13,15 & 0,14 & 13,44 & 0,20 & $-0,28$ & $-2,14$ & $-1,32$ & $-11,58$ & 0,00 \\
\hline
\end{tabular}

Another approach for the finalist's performance and realization analysis in the period 2001-2019 is presented in Table 5. Applying Student's T-test for paired samples we make a comparison between sport result (sec.) in heats, semi-finals, finals, and PB from the corresponding year of WAC. Logically with competition stages progress, we find an increase of both absolute (d), percentage (d\%), and $t$ coefficient values $-\mathrm{d}$ for heats/semi-final is 0,15 sec., and we find high values of $\mathrm{t}$ criteria - 7,09. Surprising is the small difference between semi-final/final which means that hurdlers must be close to their maximum performance for the semis in order to qualify for the finals. There is also a statistically significant difference between results from finals and $\mathrm{PB}$ for the corresponding year $(t=8,62)$.

Table 6. Correlation matrix.

\begin{tabular}{|c|c|c|c|c|}
\hline Heats & Heats & \multirow{2}{*}{$\begin{array}{l}\text { Semi- } \\
\text { final }\end{array}$} & \multirow{3}{*}{ Final } & \multirow{4}{*}{ PB for year of WC } \\
\hline Semi-final &, $433^{* *}$ & & & \\
\hline Final & ,123 &, $550^{* *}$ & & \\
\hline PB for year of WC & $248^{*}$ &, $639^{* *}$ &, $710^{* *}$ & \\
\hline
\end{tabular}

For a better understanding of interrelations between studied results from heats, semifinals, finals and PB from the corresponding year we present the correlation matrix in Table 6. From there we find that PB result correlation levels increase with competition stages progress which means improvement of performance. All correlations are logical and present levels of sport realization.
With the greatest practical contribution, and persistence in their performance (participating in finals) in WAC over the years, stand out names of the athletes in Table 7. These eight athletes have cumulative participation percentage in all WAC finals $24,26 \%$ which is a proof of their sports performance level and constancy. 
Table 7. Hurdlers with most participations in WAC finals.

\begin{tabular}{|l|c|c|c|}
\hline \multicolumn{1}{|c|}{ name } & frequency & $\begin{array}{c}\text { percent } \\
(\mathbf{\%})\end{array}$ & $\begin{array}{c}\text { cumulative } \\
\text { percent }\end{array}$ \\
\hline Allen JOHNSON & 5 & 3,68 & 3,68 \\
\hline Aries MERRITT & 4 & 2,94 & 6,62 \\
\hline Colin JACKSON & 4 & 2,94 & 9,56 \\
\hline Florian SCHWARTHOFF & 4 & 2,94 & 12,50 \\
\hline Jack PIERCE & 4 & 2,94 & 15,44 \\
\hline Sergey SHUBENKOV & 4 & 2,94 & 18,38 \\
\hline Terrence TRAMMELL & 4 & 2,94 & 21,32 \\
\hline Xiang LIU & 4 & 2,94 & 24,26 \\
\hline
\end{tabular}

\section{CONCLUSION}

After a certain period of time (7 WAC) athletics governing body managed to find an effective structural pattern for conducting the WAC in the $110 \mathrm{~m}$ hurdles disciplines, which are the most efficient, and athlete's friendly way of competing in the discipline and revealing their best performance.

Globally results of finalists from heats and semi-finals have similarities. Athletes compete in preliminary stages just to proceed to the next stage. The finals give the opportunity for maximum sport performance and ranking.

Based on hurdlers ranking in finals of WAC we define three groups based on their sport performance and realization similarities: medal winners, hurdlers rank in 4th place, athletes with a ranking between 5th and 8th place. As a separate tendency, we can mark that hurdlers from second and third groups often reach $100 \%$ of their performance abilities (register $\mathrm{PB}$ result for the corresponding year) in the semi-finals just to qualify for the final.

Using data from Students T-test we can mark that hurdlers must be close to their maximum performance for the semis in order to qualify for the finals.

\section{REFERENCES}

1. Dimova, I. (2020). Lekoatleticheski mnogoboi za deca pod 14 g. (Monografia). Bolid Ins, Sofia, ISBN 978-954-394-278-7.

2. Freeman, W. (2015). Track \& Field coaching essentials/USA Track \& Field. Human Kinetics, USA, ISBN 978-1-4504-8932-4.

3. Gigova, V. (2019). Statisticheski metodi s SPSS Statistics, NSA Press, Sofia, ISBN 978954-718-596-8.

4. Gutev, Gr. (2015). Promeni v sportnotehnicheskite harakterisitki na prepiatsvenoto biagane saobrazno kompleksnite faktori na postijenieto. Disertacia. NSA, Sofia, COBISS.BG-ID - 1272892388.

5. Jeliazkov, Tz., D. Dasheva. (2017). Osnovi na sportnata trenirovka. Bolid-Ins, Sofia, ISBN 978-954-394-222-0.

6. Karapetrova, R. (2017). Hvurliane na kopie jeni: tehnika i trenirovka (monografia). NSA Pres, Sofia, ISBN 978-954-718-493-0.

7. Lazarov, I. (2019). Upravlenie na sportnata podgotovka $\mathrm{v}$ biaganiata na sredni $\mathrm{i}$ dulgi razstoiania (monografia). Bolid Ins, Sofia, ISBN 978-954-394-243-5.

8. Niagin, Pl. (2015). Prepiatsvenite uprajnenie (kniga). NSA Pres, Sofia, ISBN 978-954718-404-6.

9. Stoykov, St., et al. (2014). Leka atletika. NSA Press, Sofia, ISBN 978-954-718-393-3.

10. World Athletics official web site (February, 2020) - https://www.worldathletics.org/ 
